\section{AIDS in Thailand}

Fulfilling all expectations, AIDS is finally sweeping Thailand at a speed that is stunning. Because of its lethal mix of cheap sex and widespread heroin addiction the country's health experts had been predicting trouble for years. And now, after last year's statistics, doctors in Thailand are speaking of an explosive epidemic. Some politicians are even whispering of a national emergency.

The first case of AIDS was reported in August 1984; it was in a homosexual Thai who had just returned from the United States. Others followed slowly, so that by the end of 1988 there were only $10-$ most of these were in gay men who were said to have contracted the virus either overseas or from visiting tourists. Clearly, this was not a Thai problem, and complacency prevailed.

But the medical authorities did move at an early stage to make AIDS a notifiable disease, so ensuring the start of blood testing. To date over two million Thais have been tested, and until the beginning of 1988 things were looking pretty good. But in that next year, the number of people reported as being positive for HIV leapt from just over 100 to 2901. In 1989 this figure rocketed to 13600 . By the beginning of this month the number of people infected with HIV had reached 14116 , of whom 14033 are still alive. And these are only the detected cases. Unofficial government projections of this figure suggest that the country presently has 30000 carriers of HIV and that this figure will rise to over one million by 1994 .

According to Dr Praphan Phanuphak, a leading AIDS physician and researcher at Chulalongkorn University, the first cases were confined to homosexual men. But infection then spread to intravenous drug users, starting the "second epidemic." The latest figures show that about $40 \%$ of heroin users in Bangkok are now infected, and as many as $51 \%$ in some northeastern provinces.

\section{Heterosexual epidemic}

And then, last year, as if to some silent signal, the epidemic swept into the heterosexual community. Until January the rate of infection among female prostitutes attending clinics for sexually transmitted diseases had been stable at between 0.3 and $0.5 \%$. By the year's end there had been an average sixfold increase in this figure across the nation.

In the northern city of Chiang Mai over $72 \%$ of "low class" prostitutes (those charging less than $50 \mathrm{baht}$ ) were positive for HIV. The equivalent figure for "higher class" prostitutes (those costing 50-100 baht and having fewer daily "interactions") was $30 \%$, and for prostitutes costing more than 100 baht the figure was $16 \%$. Dr Vicharn

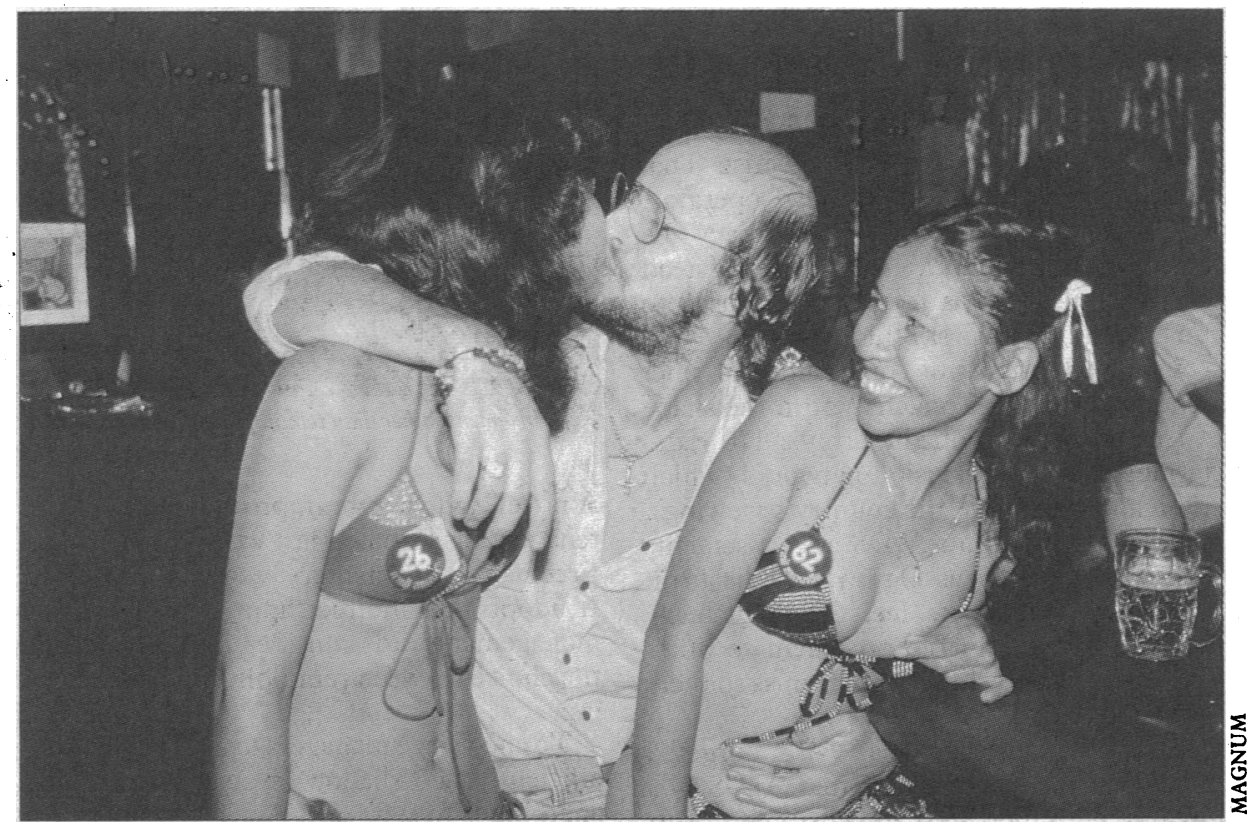

Are Thailand's days of sexual tourism numbered?

Vitiyasai of Chiang Mai University, whose study produced these figures, argues that the main route of AIDS transmission in northern Thailand is through sexual contact, which is in contrast with the position in the rest of the country, where it is primarily through needle use.

Cases in heterosexual men are turning up in increasing numbers, and there is now a clear risk of contracting AIDS to clients of certain kinds of brothel. There is also evidence of a fourth epidemic - in children.

For a developing country Thailand has an outstanding health care system and a strong research base in biomedical sciences, with many internationally recognised researchers. These resources are being channelled into some interesting research projects. At Chulalongkorn Hospital Dr Praphan's department has developed a procedure for diagnosing transplacental HIV infection using an IgM immunoblot technique and is now working on a dipstick saliva test for HIV antibodies. Clinical trials are under way to assess whether the spermicide nonoxinol 9 can reduce HIV infection when used vaginally by prostitutes, and whether gossypol (used in China as a contraceptive for men) reduces HIV activity in semen.

Physicians face treating patients with little prospect of access to expensive antiviral drugs. Dr Praphan said "I would use antivirals in symptomatic patients, but it would just not be cost effective in this country." The Ministry of Public Health was reported recently as estimating the cost of caring for one patient from diagnosis to death as 1 million baht ( $£ 25000)$. With an estimated 100000 intravenous drug users and upwards of 500000 prostitutes there are growing fears of widespread social and economic upheaval. Most of the present carriers who develop AIDS in the future will have to be cared for within their home communities, which until now have displayed only ignorance and hostility.

\section{Public education campaign}

But in the face of this seemingly overwhelming challenge to Thai society a spirited anti-AIDS programme is beginning to emerge. Early public education efforts were ignored-some say suppressed - by government fears about adverse effects on foreign tourism-last year five million tourists visited Thailand and earned the country over 9000 million baht of foreign exchange ( $\$ 225$ million). The argument now being used by health campaigners is that fighting AIDS publicly is the best thing for tourism-you stop the sex seekers and gain confidence among the kind of visitors the country needs.

A few months ago there was a surge of articles on AIDS in the Thai press, following denouncing the sex industry and calling for greater awareness about AIDS. Given the deep respect held for the royal family by Thais, this was seen to be a turning point in public opinion. Similar statements from Public Health Minister Chuan Leekpai followed closely, and, although some observers say that this has damaged Chuan's political career, his campaign is clearly associated with an irreversible shift in government policy. But undoubtedly the most colourful figure in the public education scene here statements by HRH Princess Chulabhorn 
is Mechai Viravaidya. His family planning work in the 1970s was so successful that today if you need condoms in Bangkok you must ask for "Mechais." More recently, Thailand has been treated to highly publicised condom inflating competitions, antiAIDS raids on Patpong bars by health workers in condom costumes, and a galaxy of educational material: key rings, musical cassette tapes, bedside booklets for brothels, and calendars which depict, for example, a repulsive skin disease for January and an emaciated torso for February.

But beneath his showmanship, which already has done much to desensitise Thai attitudes to AIDS, lies a shrewd operator. Realising the deadening bureaucracy he faced in government, Mechai turned instead to the army, which a few years ago used to run the country. In a skilful political move he secured the support of commander in chief General Chaovalit Yongchaiyut in the shape of free advertising on the army's 126 radio stations and two television networks (which command $60-80 \%$ of the country's viewing). The hard hitting anti-AIDS advertisements were made by Angus Ogilvy's media firm, which also waived its fee. Simultaneously the army set a valuable precedent to other employers by agreeing not to dismiss soldiers who tested as HIV positive.

Mechai's campaign has also targeted private businesses, arguing that AIDS is a threat to both their staff and customers. Soft drinks and cosmetics firms are now distributing educational material through their retail outlets, life assurance companies and banks are posting AIDS leaflets to their policy holders, and the Bank of Agriculture, which has 1.6 million accounts, has agreed to provide loans to customers who are HIV positive.

And now the government is starting its own anti-AIDS programme, with $\$ 4 \cdot 7$ million from the World Health Organisation and foreign governments and 43 million condoms from the United States Agency for International Development. Legislation is being drafted for compulsory HIV testing of prostitutes and drug users; bleach is being distributed throughout drug centres to clean needles; clinics are opening in bar areas; safe sex brothels have been launched; and AIDS wards are planned for hospitals.

With 700 new carriers of HIV detected each month, $86 \%$ of whom use needles, Mechai sees his campaign as a race to prevent sexual intercourse becoming the main route of disease transmission.

This will be a very tough race. In Thailand prostitution is part of the social fabric; it is institutionalised by big business, an economic necessity for poor "up country" girls, accepted as normal for married Thai men, and a titillating attraction for many foreign tourists. It is true that the sex industry has been hit temporarily by AIDS fears in some regions. For example, in the border town Hat Yai brothels were closed and hotel rooms left empty when Malaysia started random blood tests for its citizens who were returning from Thailand. But elsewhere business is thriving and the tourism authority of Thailand reports a steady increase in visitors. - JOE ANDERSON

Brighter wards

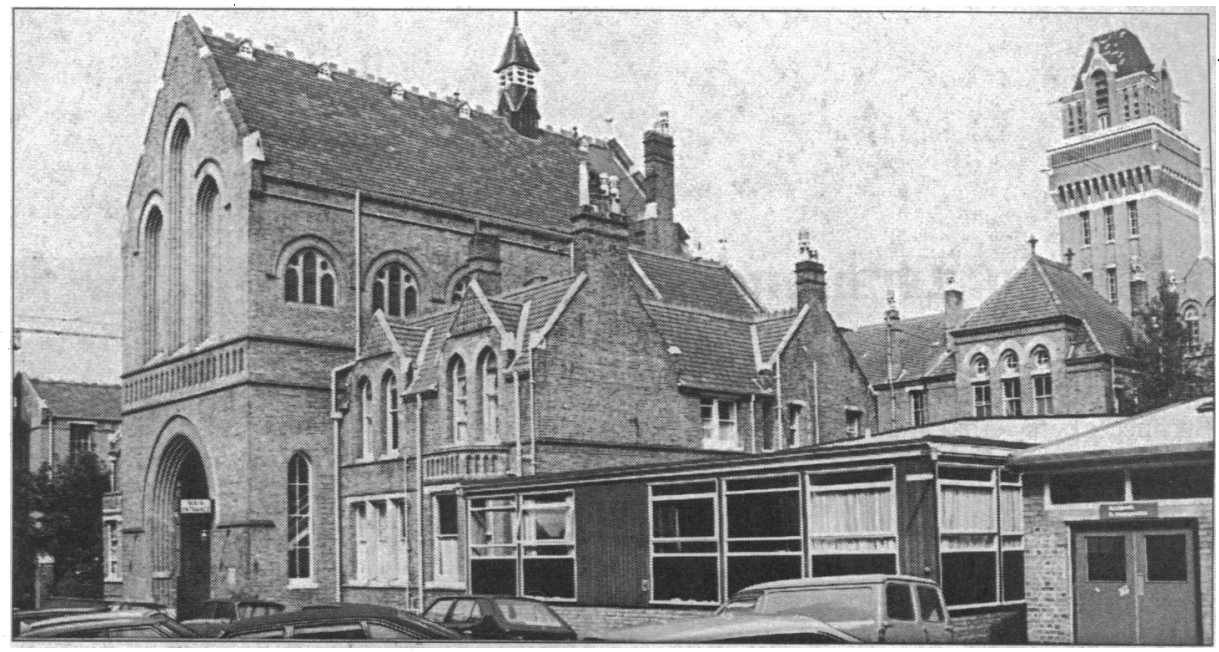

Refurbishment rather than rebuilding will make economic sense when capital charging begins

A novel campaign to improve hospital maintenance was initiated last week by $\mathrm{Mr}$ Roger Freeman, parliamentary secretary for health. It adopts the indirect approach of causing managements to consider more carefully the choice between rebuilding and refurbishing.

To encourage managers to use capital more efficiently a "shadow system" of capital charging is to start on 1 April. It will last for 12 months until a formal system of capital charging between regional and district health authorities comes into force under the NHS

\section{"Striking Sudanese doctors to be hanged"}

Reports from Khartoum suggest that several Sudanese doctors are about to be executed for participating in a doctors' strike last November. The strike followed the arrest and dismissal of some of their colleagues and the banning of the Sudan Doctors Union after an army coup in June.

One of the doctors whose execution is believed to be imminent is Dr Maamun Hussein, a consultant obstetrician and gynaecologist at Khartoum Hospital and former secretary general of the Sudan Doctors's Union. Last month a campaign organised by Amnesty International was credited with getting the death sentence on Dr Hussein commuted, but this now seems not to have happened: four doctor's including Dr Hussein have been given "the red robe" to wear, which indicates that they will be killed soon.

The BMA took up the case of Dr Hussein after he was sentenced to be hanged in December and has renewed its campaign of support with the recent news. It has written to his excellency Lieutenant-General Omar Hassan Al-Bashir, Sudan's head of state, expressing its grave concern about the abuse of human rights and the use of and Community Care Bill. Capital charges will mean that new hospital buidings will have to be properly depreciated and health service managers will have to pay regard to the consequences for revenue expenditure of capital spending programmes.

Mr Freeman said: "It seems to me to be economic nonsense to demolish a soundly constructed building simply because it looks shabby. Large wards can be transformed into bright, compact, patient friendly units at a fraction of the cost of rebuilding."-JOHN WARDEN torture and the death penalty in the Sudan. The BMA "deplores the torture of $\mathrm{Dr}$ Hussein and his colleagues, deplores the breaches of internationally agreed standards of justice in these cases, and requests the Sudanese government to commute the death sentences imposed."-TONY DELAMOTHE

\section{Lords approve embryo research}

Medical science overwhelmed moral objection in the House of Lords last week when an attempt to prohibit embryo research was heavily defeated by 234 votes to 80 . In a free vote with only conscience directing it the peers rejected an amendment by the Duke of Norfolk and ensured that the main purpose of the Human Fertilisation and Embryology Bill was achieved. This is to allow research on in vitro human embryos up to 14 days old under the control of a statutory licensing authority.

The decisive margin of the vote in the Lords will influence members of parliament when the bill arrives in the Commons. Although the majority was predisposed, it was plainly swollen by one speech in particularthat of the medical peer Lord Walton, a former professor of neurology and past president of the BMA.

Lord Walton supplied the House with the 
scientific facts on which to base a moral judgment. He explained the present state of genetic research and illustrated how crucial development would be frustrated if embryo work were to be banned. Research within the 14 day limit and under strict control by a licensing body was not only compatible with the Christian ethic but would have untold benefit for human life. "I find it very difficult personally to see how anyone deeply concerned about the welfare and suffering of humanity can fail to recognise the beneficial effects of such research," he said.

Opponents of research based their case not only on the fundamental argument about according total respect for the human embryo but also on the grounds that limited research would be the "slippery slope" to later extension. Lord Robertson of Oakridge chastised the medical profession for allowing abortion to "get out of hand," in the sense that the 1967 Abortion Act would not have been passed if parliament had been aware that it would result in upwards of 150000 terminations a year.

Abortion amendments to the embryology bill, aimed at reducing the legal time limit to 18 weeks, will be moved in the Commons. Supporters have been encouraged by a High Court ruling suggesting that termination is illegal in cases in which the fetus could have independent life, however short.JOHN WARDEN

\section{Juniors' hours: Mrs Bottomley plays for time}

Junior doctors now see legislation as the only way of curbing excessive hours of work after their representatives emerged disappointed from a one and a half hour meeting with the Minister for Health last week. They had expected government action to carry forward the initiatives started in 1988 and 1989 (box). But Mrs Virginia Bottomley offered only "more talks" with the NHS management, the Joint Consultants Committee, and the royal colleges. Moreover, she refused to do anything to improve the derisory payments for out of hours work.

The government's decision not to take any direct action to solve the problem will anger the Hospital Junior Staff Committee, which meets on 1 March, its chairman, Dr Graeme McDonald, forecast. On average, he said, junior doctors were working over 80 hours a week, and $60-70 \%$ of the 28000 junior doctors in the United Kingdom worked more than 72 hours - some as long as 128 hours.

Junior doctors believed that their case had been strengthened by research published last week, which showed that among the doctors surveyed the average number of hours of duty was 90 a week. Hours worked by house officers in teaching hospitals were particularly long, averaging 121 hours of duty and 86 hours of work when weekend duty was included ( $p 472)$.

Dr McDonald did not think that the committee would decide to take industrial

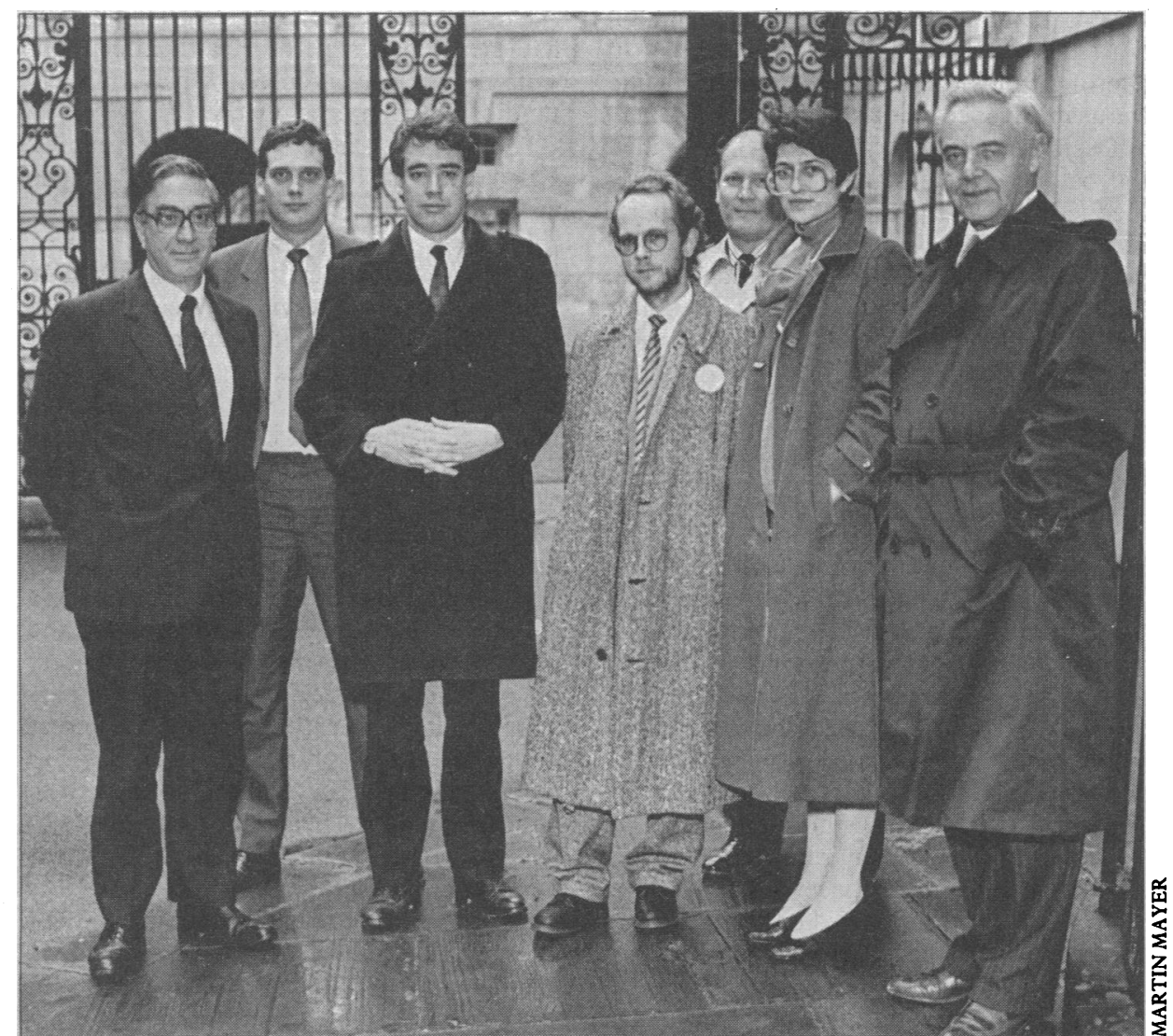

On the way to see Mrs Bottomley. From the left, Dr Ian Field, BMA secretary; Dr Stephen Hunter, vice chairman, HFSC; Dr Graeme McDonald, chairman, HFSC; Dr Andrew Carney, vice chairman, HFSC; Dr Feremy Lee-Potter, vice chairman, CCSC; Dr Angela Thomas, vice chairman, HFSC; and Dr fohn Marks, chairman of BMA council

action or any other steps that could harm patients. It was more likely to call for a campaign to make the public aware of the dangers of being treated by tired doctors.

The HJSC resolved last year that legislation was necessary, and the BMA will try to seek an amendment to the NHS and Community Care Bill, which is now going through parliament. During the last parliamentary session the committee supported a private member's bill to impose a maximum of 72 hours a week by 1992; this failed to make progress. - LINDA BEECHAM

\section{Policy and initiatives}

- The BMA's policy is that junior doctors' hours should be reduced to 72 hours a week, and the government shares this aim. The HJSC wants this achieved by 1992 with an eventual reduction to 60 hours. In the long term the HJSC's policy is that continuous duty should be limited to a maximum of 36 hours

- In 1988 regional health authorities were asked to take action to reduce onerous rota commitments. Reports from the working parties set up show that by September $1990,13 \%$ of junior doctors will be working rotas of one in three or worse

- In 1989 , in consultation with the HJSC and the JCC, the Department of Health set up nine pilot studies to see whether reductions in average hours of duty to 72 a week could be achieved within existing manpower and service constraints.

\section{Mutiny on the flagship, but only a third voted}

Staff at Guy's and Lewisham Hospitals in London have voted nine to one against the hospitals becoming an NHS trust. Guy's was chosen as one of the first hospitals to implement resource management - a prerequisite to self governing status - and together with Lewisham is one of the 79 units listed in November 1989 as being expected to proceed with applications for self government in April 1991.

Although the government has said repeatedly that any proposals for change would need to carry "the substantial commitment of those likely to be involved in the new management," it has consistently turned its back against ballots despite amendments requesting ballots laid during the committee stage of the NHS and Community Care Bill. So the joint staff side at Guy's Hospital organised its own ballot with help from the Electoral Reform Society. The 3000 consultant, nursing, administrative, technical, and cleaning staff were all included, but only a third responded. Individual staff groups plan to hold their own ballots - consultants at Guy's and Lewisham Hospitals will hold a secret ballot next month and local general practitioners will also be balloted. This is likely to be the pattern in other major hospitals on the "list of 79," which are awaiting the outcome of the judicial review brought by Professor Harry Keen (of Guy's 
Hospital) and his colleagues. They maintain that the government has acted illegally in allotting funds to prepare for self governing status in advance of legislation.

Despite the low turnout the BMA called the ballot result a significant snub for $\mathrm{Mr}$ Kenneth Clarke's proposals, and the general secretary of the Confederation of Health Service Employees, Mr Hector MacKenzie, said that the government couldn't say that it had the support of the people in the health service. - LINDA BEECHAM

\section{Testing the market}

It is 1991. The Numberside Health Authority wishes to buy services for its residents in the new internal market. The two local NHS trusts, Oneport and Fourton, are offering general surgical services at $£ 684$ and $£ 541$ per case respectively. The teaching hospital in the region enters the market at a price of $£ 300$ per case. Should Numberside send some of its patients to the teaching hospital, or should it let contracts to the local trusts? If a decision is made to purchase services locally should both hospitals be supported or should Foureven though this would mean additional travelling for patients currently served by Oneport? And if services are transferred to Fourton will it have the capacity to meet the extra demand?

These are some of the questions raised by a hospital contracting simulation game prepared by the Northern Regional Health Authority with assistance from Peat Marwick McLintock Management Consultants. The purpose of the game is to help managers prepare for the introduction of contracting arrangements in 1991. Players comprise three groups of managers, representing a district health authority and two NHS trusts. There is also provision for a GP budget holder, referred to as Dr Jekyll, to take part. ton be favoured because of its lower cost,

The game takes the form of a training pack that the Department of Health hopes will be used by managers to gain a better understanding of the internal market.

The most revealing part of the training pack is the list of conclusions and lessons intended for use at the end of the game. This makes it clear how crude and limited contracting will be in the early stages. For example, the cost of services is measured only at a specialty level, and it makes no allowance for case mix. Similarly, the game does not address quality issues. As the guidance for trainers explains: "This is not surprising; it is quite clear that current, mainly input and process oriented, information systems are not going to be able to deal adequately with quality issues."

The main value of the game for managers will be to encourage thinking about the differences between the roles of purchasers and providers. By deliberately splitting participants into health authority and NHS trust groups the game should help to develop understanding of the different perspectives of those around the negotiating table.

Equally, the simulation may highlight the dangers of purchasers and providers adopting an adversarial approach to each other. By illustrating the pitfalls of stand off relationships, the game should offer a useful warning to those managers contemplating a macho management style.

The main weakness of the game is its neglect of the objectives that contracts are meant to serve. Unless health authorities are clear about the goals they are pursuing it will be impossible to judge whether contracts have succeeded or failed. In particular, authorities will need to determine their commitment to such values as access, patient preferences, and service effectiveness before they can engage in sensible discussions with providers. Managers who have given some thought to what they are seeking to achieve will be better placed to make these judgments than those who have not. - CHRIS HAM

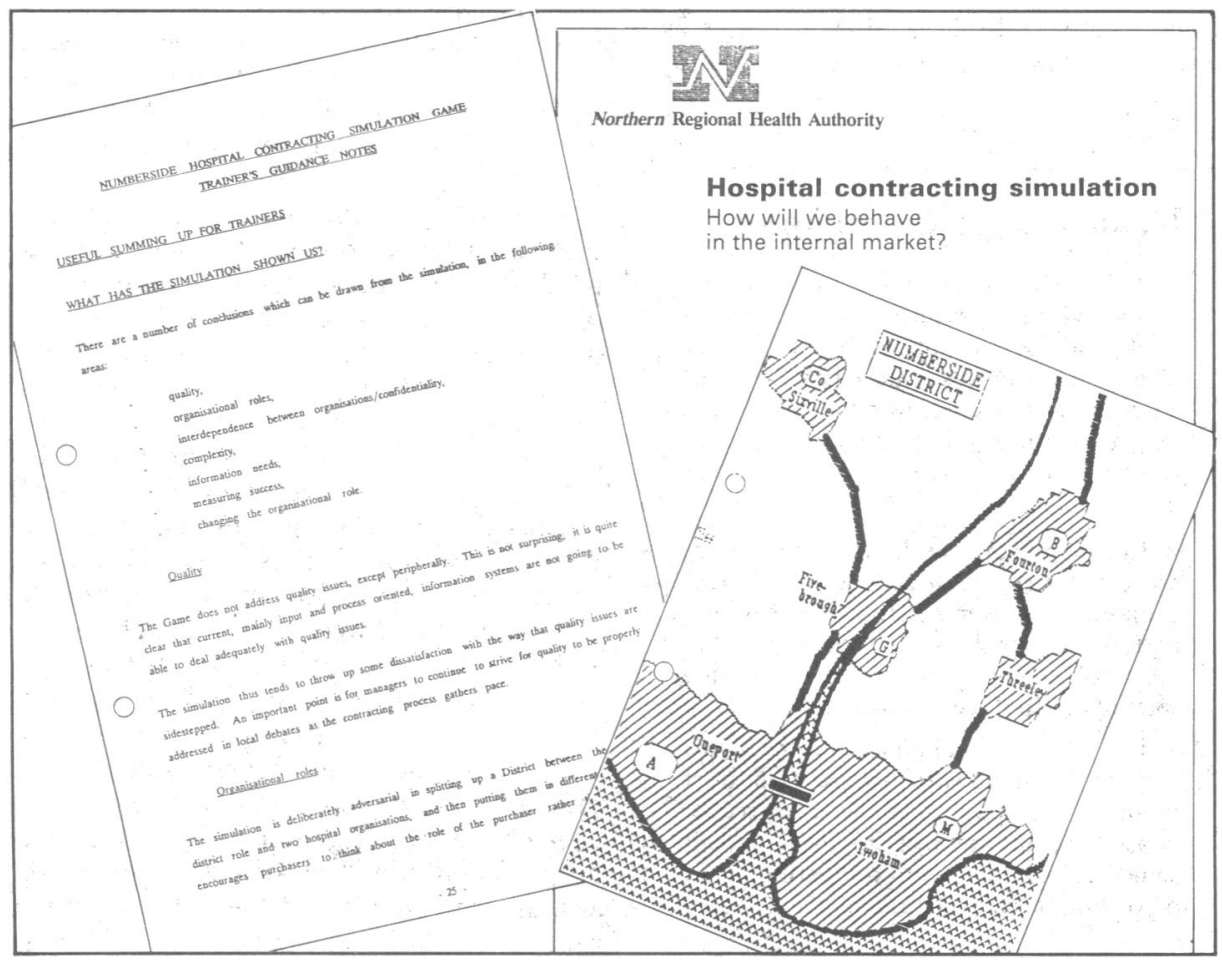

Appeal Court upholds High Court decision on mianserin

Organon Laboratories, which won a court injunction last year stopping the Department of Health from warning doctors of the hazards of mianserin, an antidepressant linked to at least 18 deaths, succeeded last week in the latest round of its legal battle with the department. Three Appeal Court judges upheld a High Court ruling quashing a decision by the department to restrict the use of mianserin (trade name Bolvidon) in patients over 65 . Organon went to court after the department proposed to limit the drug's product licence to patients under 65 , except for those with glaucoma or symptoms of prostate enlargement or those failing to respond to other antidepressants.

The injunction stopped the Committee on Safety of Medicines (CSM) printing a warning in Current Problems about over 130 reports of blood problems in patients taking mianserin, including the potentially fatal agranulocytosis. Mianserin is the third or fourth bestselling antidepressant in Britain. After its High Court victory the company agreed that the figures could be published, but not the recommendation that mianserin could be used only if other antidepressants failed.

Giving judgment, $\mathrm{Mr}$ Justice Mustill said he agreed with the High Court that the department, the CSM, and the Medicines Commission had misdirected themselves in deciding they could not consider mianserin's relative safety if taken in overdose when making decisions on product licences.

If the High Court ruling was upheld, the department claimed, it would have to take into account risk in overdose with every drug, and compare every drug's safety in overdose with that of other similar drugs. His lordship did not accept that reading of the ruling. It was for the CSM and the Medicines Commission to decide whether evidence of safety in overdose would be valuable. If they decided that it would not be useful they were free to exclude it.

The department argued that under the Medicines Act it, the commission, and the CSM had to consider only safety "for the purposes indicated in the licence" when deciding whether to vary a licence. But Lord Justice Mustill said that to read the words in such a narrow way would act against public health and safety. It would mean that if the department discovered that a drug was safe in the intended dosage but lethal if taken in even moderate excess it could not reconsider the original risk-benefit analysis. "This result strikes me as so absurd that it cannot have been within the contemplation of parliament."

It followed, therefore, that the risks attaching to misuse could properly be brought into account. It was plain also that the department could pay regard to the risks associated with other drugs intended for the same purpose. 
The judges also dismissed an alternative argument by the department that its decisions were governed by a European directive on medicines, since EC directives override domestic law. Article 11 of the directive says that a licence should be suspended, revoked, or refused if the product proves "harmful in the normal conditions of use."

Lord Justice Mustill said that the United Kingdom had not fully implemented the directive and was therefore in breach of its treaty obligations to harmonise the law on product licences. A state could not invoke a directive against an individual or corporation if it had failed in its duty to carry the directive into local law. - CLARE DYER

\section{Information overload?}

Reports from the Department of Health indicate that massive investment in computer technology (up to $£ 130 \mathrm{~m}$ over the United Kingdom) will be needed to enable health authorities to fulfil their future roles as health care purchasers. This investment would be on top of that so far announced for the implementation of the government's NHS review and in addition to the computer investment necessary to run resource management in hospitals.

The estimates of up to $£ 130 \mathrm{~m}$ in capital investment and nearly $£ 35 \mathrm{~m}$ in annual running costs are contained in the government's latest NHS review working paper, Framework for Information Systems: an Overview. This working paper, the 11 th since the publication of Working for Patients, is the first consultative one. It is, however, also the longest and, in its 15 annexes and summaries which run to over 550 pages, contains much more detail. Everything from the problems of attaching postcodes to patients' records to information on the unique identifying number that patients will need to enable hospitals to keep track of the treatment they receive are covered by the paper.

One difficult area as far as obtaining information is concerned is the private health care sector. The working paper recommends that comparative data on, for example, lengths of stay, case mix, and, importantly, prices will be needed by purchasers (by and large district health authorities and general practitioner fund holders). Whether the desire of private sector staff for commercial confidentiality will be overcome by their necessity to disclose information to purchasers in order to win contracts remains uncertain.

It is not only purchasers who will require information from the private sector. The Department of Health will require information about provider "stock" and the "capacity to treat"-for example, bed numbers and services both public and private. It will need this information to devise interventionist strategies to ensure that the provider market works. As the department admits, "Market forces alone will not ensure that the right services are in the right place at the right time

\section{White paper money}

Implementing Working for Patients is likely to be an expensive business. Since April last year the government has provided an additional $£ 85 \mathrm{~m}$ for the health service in England to fund initial work on the white paper. In the coming financial year, as the recent white paper on public expenditure stated, the government plans to provide an extra $£ 300 \mathrm{~m}$.

The $\$ 300 \mathrm{~m}$ for next year does not include the estimated $£ 165 \mathrm{~m}$ costs of setting up and running the computer systems that were suggested by working paper 11 .

The grand total bill of $£ 550 \mathrm{~m}$ for implementing the white paper, however, does not include the cost of the time spent by managers, clinical staff, nurses, planners, accountants, and other health service personnel on the implementation. Whether the eventual benefit of the government's review will outweigh even the white paper's implementation costs is a calculation no one has yet attempted.-JOHN APPLEBY

in the early years of the operation of the internal market."

The information that the market will require will be extensive and, as the working paper points out, will need to be accurate and timely. The costs of unreliable information systems could be great, possibly leading to the bankruptcy of providers and failure of purchasers to meet adequately the health needs of their populations within their budgets.

For purchasers such as district health authorities the key information document will be the contract. The working paper recommends a "minimum data set" for contracts, which builds on current statistical forms introduced in the past few years as part of the Körner review of health service statistics. Ethnic origin and social class are two new data items that the working paper recommends. - JOHN APPLEBY

\section{GP budget holding: an American view}

Where intellectual antecedents can be discerned in Working for Patients they usually turn out to be American. Timely, therefore, to ask what Americans think of the plans so far. The King's Fund Institute has recently published the most detailed response. It comes from two American health care experts who have concentrated on budget holding by general practitioners and given it a qualified thumbs up.

The authors do, however, confess themselves to be "proponents of market orientated primary care based delivery systems" and "a bit naive regarding the British political process."
Breakdown of government expenditure planned for implementing "Working for Patients"

1989-90: $£ \mathrm{~m}$

Improving general management $\quad 5 \cdot 7$

Extra finance personnel $\quad 11.5$

Setting up asset registers

Extra public health medicine posts

Implementation of medical audit

Department of Health

Appointment of 35 of the 100 extra consultants

"Roll out" of resource management initiative

Total

1990-91:

Hospital and community health revenue

Hospital and community health service: capital

Family health service authorities

Total

$30 \cdot 0$

They list four desirable outcomes of budget holding:

- Increased integration between primary and secondary care sectors

- Increased sensitivity to consumer needs

- Providing a "fertile incubator for NHS innovation"

- Allowing an appreciable private sector role while helping to ensure overall coordination and social equity.

The authors have a poor opinion of the strengths of British general practice; they consider budget holding an improvement because it would remove the current "less than desirable" financial incentives for doctors to refer a healthy but troublesome patient. They also assert that the absence of fees for consultations contributes to "consumers requesting services that are not needed." Drawing on the American experience, the report commends the role of general practitioners as being fiscal as well as them acting as clinical gatekeepers. On management, the authors state that all general practitioners should become intimately concerned with their practice's financial arrangements.

The authors have devised alternative financial risk arrangements to minimise financial incentives for doctors to underservice patients, replacing the single capitation fund that had been envisaged. These proposals are attractive particularly because they ensure that general practitioners should not bear a large financial risk for the services they themselves do not deliver. The need for a proper system of pricing hospital services is emphasised, and the impossibility of the government's timetable is shown.

Clearly, adequate quality controls, which the report recommends as essential, are not even in place in the United States and it is 
interesting that quality control systems initially introduced there were really cost control systems, dressed up for the medical community as quality care monitoring. The inherent incentives for general practitioners to seek a list of select clientele is overcome, in the report, by adopting adjustments for case mix. It seems that at least some health maintenance organisations have been shown not to care adequately for those from lower social classes, which has led the authors to recommend a pinch of RAWP (the Resource Allocation Working Party's formula) and a spoonful of the Jarman index to make the system palatable. The report also highlights the attractiveness to budget holding practices of registering private patients.

Nothing is said of the adverse relations among hospitals, among practices, and between doctors and patients in a market oriented health service, because comparison of health maintenance organisations with the NHS is outside its scope. Nor does it address the issue of the dramatic drop in applications of British graduates to join vocational training schemes. - ANDREW HARRIS

GP Budget Holding in the UK: Lessons from America is available from the King's Fund Institute, 126 Albert Street, London NW1 $7 \mathrm{NF}$, price $£ 5.95$ plus $60 \mathrm{p}$ for postage and packing.

\section{User leaflets}

The brown bottle labelled "The elixir: take as directed" is headed for the museum, probably for some future display case captioned "medical paternalism." From 1 January 1992 every medicine will have to be accompanied by a user leaflet, which will make the British National Formulary seem laconic (box). Last month the Royal Society of Medicine turned its attention to the topic.

Participants at the symposium were told of the difficulties of producing a leaflet for every medicine that was comprehensive, legally defensible, and not unduly alarmist. For example, the adult British population has an average reading age of 9 years and speaks 150 different languages. Phrases such as "if

\section{This week's contributors:}

Joe Anderson is a medical policy researcher in Bangkok

John Appleby is the BMF's economics correspondent

Linda Beecham is an assistant editor of the $B M F$

Tony Delamothe is an assistant editor of the $B M \mathcal{F}$

Clare Dyer is the BMF's legal correspondent

Trisha Greenhalgh is a freelance medical journalist in London

Chris Ham is a fellow in health policy and management at the King's Fund College, London

Andrew Harris is a general practitioner in London

John Warden is the BMF's parliamentary correspondent symptoms persist, consult your doctor" and pictorial warnings to avoid alcohol may be over some people's heads. Finding out what people understand is still in its infancy: what is already clear is that expert communicators will have to get even more expert.

But what do people want anyway? Certainly more than they are getting: Professor Charles George of Southampton University has found that $54 \%$ want comprehensive information while $43 \%$ would be happy with short, snappy points. Too bad, then, that without the directive so few would receive anything: even with leaflets available research has shown that general practitioners passed them on to only one in five patients (favouring the higher social classes), with pharmacists performing only slightly better.

But couldn't all this extra information confuse patients or lead the more suggestible to develop the side effects they read about? Rabbi Julia Neuberger, of the Patients' Association, argued that there was little evidence for this. And Professor George reported work that suggested the opposite. His research has shown that leaflets improved patients' knowledge about their medicine, had no detectable effect on compliance with long term treatment, and may have improved compliance with short term drugs such as antimicrobial drugs. For most drugs no spurious side effects could be attributed to the package inserts, although leaflets for benzodiazepines may have had adverse psychological effects.

Even so, the Southampton studies found that perhaps one third of patients found the leaflets worrying. But Rabbi Neuberger defended the rights of adults to be told the risks of a treatment and to worry if and when there was something to worry about. She was concerned that the information was to be directed at the "user" rather than the patient. For radiopharmaceuticals or drugs administered to hospital inpatients the user may be a doctor or nurse, and the patient could still be kept in the dark. She also condemned the decision that certain indications could be

\section{EC directive 89/341}

By 1 January 1992 all medicinal products marketed by European Community member states must be accompanied by a package insert stating the following unless all such information appears on the package label

- Name and constituents of the product

- Therapeutic indications (may be omitted in certain cases)

- Contraindications and interactions

- Instructions for use

- Main side effects with approximate frequency

- Expiry date

- Advice on storage and safe disposal

- Warning to keep out of reach of children

- Manufacturing data (product licence number, batch number, etc).

The information must be presented in a form that is clear and comprehensive to the patient and in the official language of the member state.

omitted from the information leaflet in the case of, for example, anticancer drugs. In the new climate of collaborative rather than paternalistic health care, she argued, informed consent for any treatment is mandatory and is impossible without honest information.

The legal side of user information leaflets was addressed by Mrs Diana Brahams, barrister at law. In previous litigation legislation has tended to find in favour of the doctor's duty rather than the patient's rights. The doctor has no absolute obligation to provide any information at all with a prescribed drug, and the forthcoming European Community directive will not directly alter this. In a case of drug injury the doctor

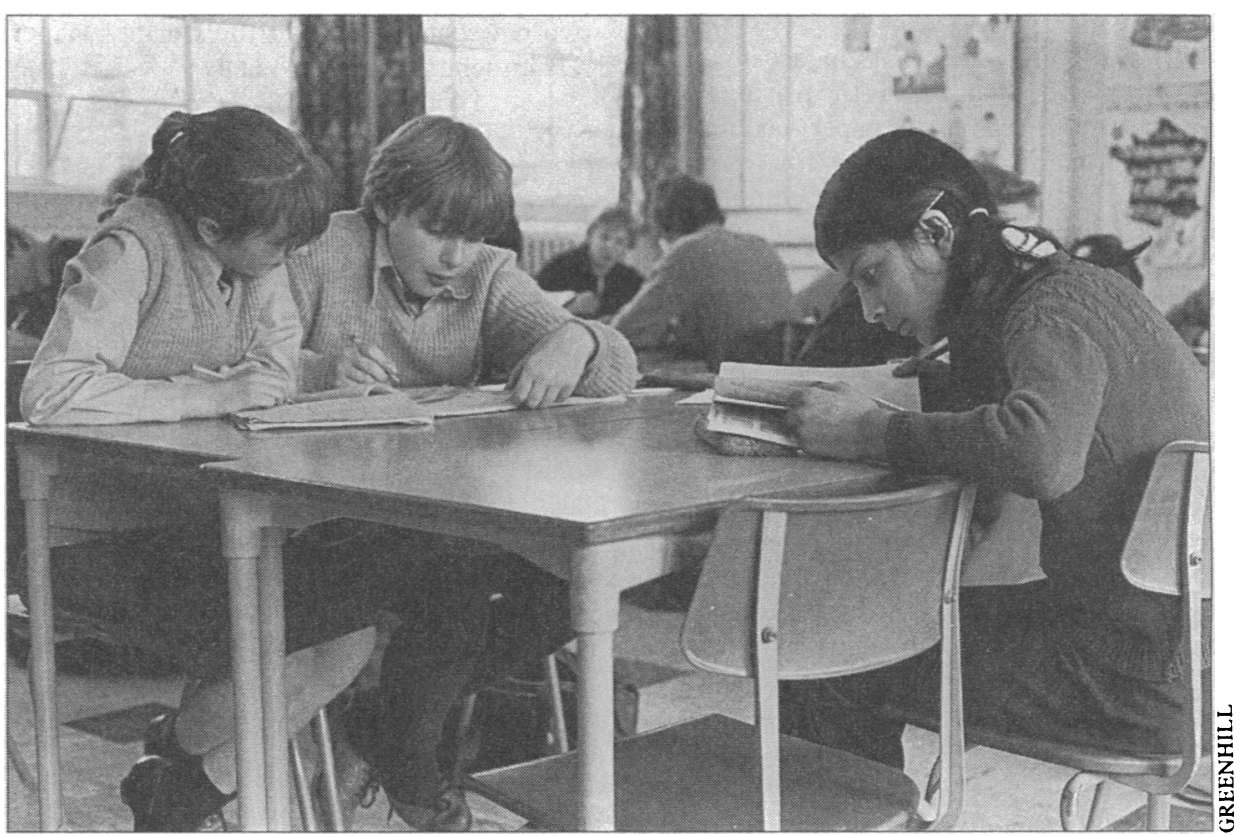

Information leaflets must be aimed at people with an average reading age of 9 years 
may be sued only in negligence. It must be shown that the doctor's "duty of care" has been breached and that the injury was foreseeable. The drug manufacturer, however, can be sued for liability, which has a stricter meaning under the Consumer Protection Act 1987. The manufacturer, and not the doctor, is therefore legally responsible for warning of potential adverse effects. Small wonder, then, that no representative from the pharmaceutical industry challenged Rabbi Neuberger's call for compulsory and comprehensive package inserts. Intended to support the consumer's right to information, the European Community directive on package inserts may simultaneously be reducing his or her right to redress.

The practical problems of issuing a standard information leaflet with every course of treatment will almost certainly be overcome by the dispensing of manufacturers' original packs. Some drugs, such as the contraceptive pill, are already supplied in this form. Why most tablets and capsules are still supplied to the retailer in plastic buckets and counted out manually by the pharmacist is something of a mystery: original pack dispensing would improve hygiene, increase shelf life, and prevent errors of dosage and labelling. It would also provide a vehicle for the user information leaflet. There are, however, drawbacks: loyalty to brand names would put up costs as would the need to prescribe a 28 day pack for 14 days' treatment. Blister packs present safety hazards and lack standard sizes - so the patient may receive 28 days' supply of one drug and 30 of another. On these and other problems-such as the temptation to make the information leaflet promotional and how to package drugs for hospital inpatients - the debates are just beginning. - TRISHA GREENHALGH

\section{Letter from Westminster}

\section{Counting the cost of sick notes}

In the course of this year general practitioners will sign upwards of fourteen million sick notes. As clinical evidence these certificates underwrite billions of pounds in state welfare payments funded by national insurance contributions and general taxation.

In terms of protecting the public purse is there any reason for doctors to feel a sense of guilt about dispensing so many sick notes? The answer is "yes" if they read the recent National Audit Office's (NAO) report on invalidity benefit (27 January, p 216). But it is "no" if they heed the evidence given to the follow up inquiry by the Commons public accounts committee last week.

Let us begin with the NAO, whose chief, Mr John Bourn, the Comptroller and Auditor General, is charged by parliament to report on "economy, efficiency, and effectiveness" in the use of public resources. Long term sick pay, known as invalidity benefit, is clearly a prime candidate for Mr Bourn's attention. In six years its cost has almost doubled to more than $£ 4$ billion.

To qualify for invalidity benefit a claimant must be incapable of work, as certified by a doctor. Once incapacity has lasted for six months the doctor may advise the patient to refrain from work until further notice. This is the key decision that underpins a benefit system worth a basic $£ 43.60$ a week to the recipient, though additions can raise it to over $£ 100$ a week for a family man.

This year some 1300000 people will be drawing invalidity benefit. They constitute the walking wounded of the unemployed. Unlike the dole queue, however, their number can only grow. Decreasing mortality is the chief medical factor involved. People who a few years ago would have died from a stroke or heart attack are kept alive but may not be capable of returning to full time work. They will draw benefit for the rest of their lives. Almost one in eight have already been on benefit for more than 10 years. The most common causes changed little in the 1980 sheart disease $23 \%$, musculoskeletal-mainly arthritis and backache-24\%, mental disorders $16 \%$, and respiratory problems $10 \%$.

Given the crucial part that sick notes play in the control of benefit, the NAO set out to discover whether general practitioners were aware of their obligations in signing medical statements. The conclusion was that doctors were a touch too soft for the NAO's liking. It found "a degree of uncertainty" among general practitioners about their responsibilities in considering whether or not an individual was capable of work.

The report went on:

The National Audit Office conclude that to a significant extent general practitioners appear to be overlooking the requirement to consider the individual's capacity for alternative work. General practitioners also appear to be giving too much weight to family and social circumstances, although there are occasions when these factors should be properly considered.

With clearer guidance and training for general practitioners in diagnosing benefit sickness the NAO believes that significantly fewer people would qualify, with potential savings amounting to $£ 11 \mathrm{~m}$ a year for every $1 \%$ reduction. So are doctors to blame as the NAO report patently implies?

\section{Doctors defended by DSS}

Not if you listen to Mr Michael Partridge, permanent secretary at the Department of Social Security. Mr Partridge, of course, is the impartial guardian of the benefit rules which parliament has given his department to administer. But there was no attempt to suggest that family doctors were bending the rules when he appeared before the public accounts committee on 7 February. Strictly speaking, it is the department, not the doctors, who assess and pay benefit.

Quite firmly, Mr Partridge defended a doctor's right to give weight to non-medical factors. His testimony is worth putting on record. He said:

It is undeniable that the general practitioner's first duty is to his patient, rather than to the department or anything else. It is he who knows the patient, his condition, his family circumstances and the sort of work he does. It is a matter of opinion, not fact, and it varies among GPs. I would not have it otherwise. One needs to match doctors and patients.

And contrary to the impression given by some government apologists, the department is not squeamish about conceding a direct

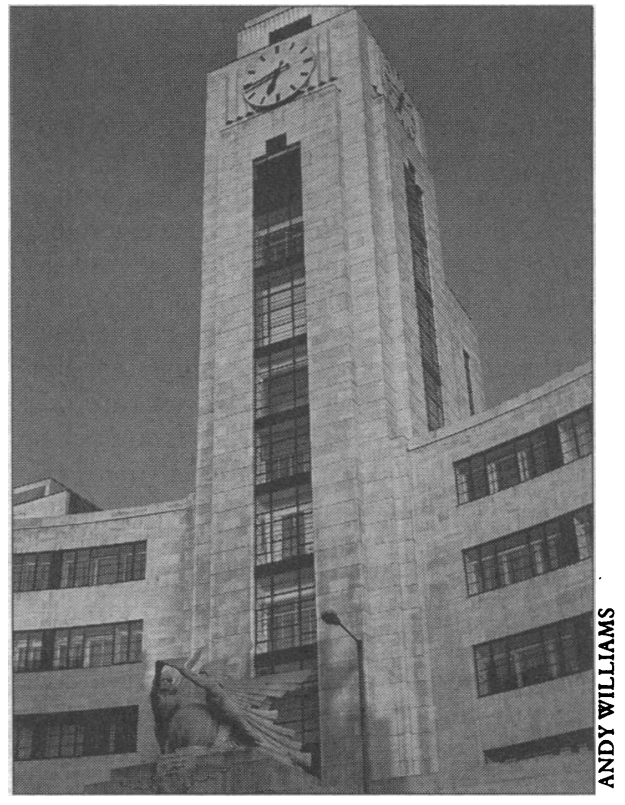

The National Audit Office is charged to report on "economy, efficiency, and effectiveness" in the use of public resources

link between unemployment and ill health. Since closure of the shipyard in Sunderland claims for invalidity and sickness benefit have gone up, and Mr Partridge had no doubt there must be some connection. Similarly, he accepts that the growth of one parent families does affect the medical condition of claimants and their ability to take a job.

As for training general practitioners on certification work, the department is reluctant to insist that it should be in the curriculum if course organisers attach greater priority to clinical and organisational matters. But to qualify for the educational allowance in the new contract from this April doctors will be required to attend courses on service management. That will give the department a lever to include instruction on signing sick notes.

There is also to be a revision of the 1986 handbook for doctors, but this will await the verdict of the public accounts committee. Will it mean a squeeze on doctors issuing sick notes? The political balance seems to be against that happening. - JOHN WARDEN 


\section{Wielding the propaganda weapon}

Propaganda is a recognised if not always welcomed activity in a democracy. The word has been tainted by gross abuse of the practice in twentieth century dictatorships, but it started life in 1622, when the then pope set up the Roman Catholic Congregation of the Propaganda. This was a committee of cardinals charged with "having the care and oversight of foreign missions." That fact comes from the Oxford English Dictionary and is accompanied by a more modern definition of "any association, systematic scheme, or concerted movement for the propagation of a particular doctrine or practice." That is sufficiently comprehensive to cover what governments, political parties, pressure groups, and, yes, even respectable institutions like the BMA all practise to disseminate their messages to anyone who will listen.

Of course any responsible organisation avoids propaganda that is too exaggerated, too frequent, or too biased. If it does not the result is counterproductive, as the BMA almost discovered when critics condemned that final poster of its advertising campaign that attacked Kenneth Clarke. (A case of a poster too far, perhaps.). Governments in particular should be careful in their use of propaganda because they have immense power in the dissemination of information:

- A government's access to information vastly exceeds that of any other groupincluding the media

- As executor of public policy a government largely decides the content of policy decisions - A government can usually be selective about how much information on decisions is released

- A government can nearly always control when decisions are to be announced

- Substantial resources are available to a government for disseminating information.

\section{BMA at disadvantage}

Opposition parties, the media, pressure groups, and organisations such as the BMA are plainly at a disadvantage in combating government propaganda even if the authorities "play fair" - and I acknowledge that, like love, war, and, nowadays, cricket, politics is rarely fair. But the temptation is great when a government is clearly under political pressure to move from acceptable propaganda to unacceptable disinformation. To draw a clear boundary between the two is as difficult as defining national boundaries in the Balkans. There has been much speculation and accusation in the media about this government's manipulation of information, and I believe that there have been instances where the government has misused its powers to the detriment of the NHS.

Since January 1989 when the NHS review was published ministers have claimed that the proposed reforms would provide greater

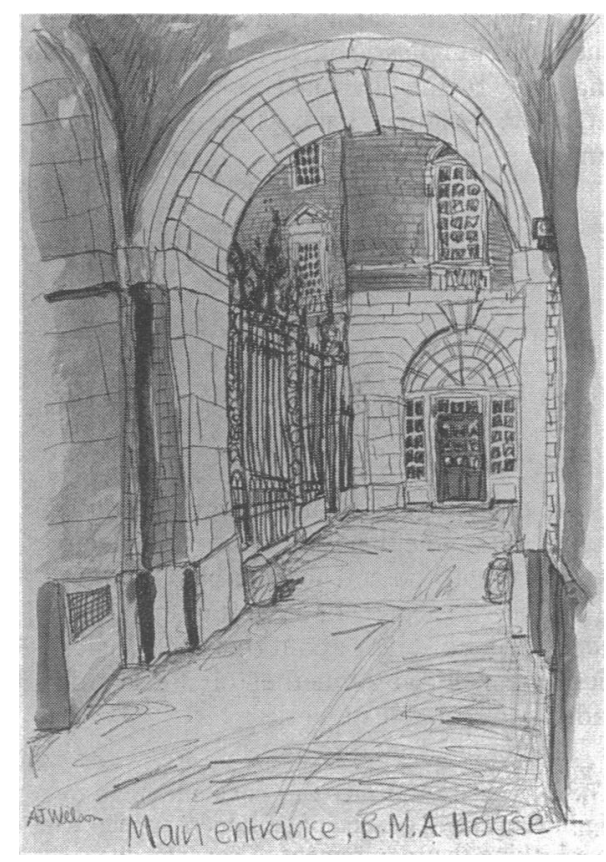

pay had been calculated on the basis of the supposed average hours contracted. The Department of Health's handout certainly gave the impression of a well rewarded group of doctors, failing to explain clearly what the rates represented. Was this just careless, hasty presentation, or another bout of disinformation?

While you are judging that question let me continue with another extract from $\mathrm{Dr}$ Tehan's letter:

Don't people realise that those [overtime] hours spent working at least equally as hard are rewarded by payments at only one third of our basic hourly rate?. . What junior doctors really want is shorter hours and reasonable rates of pay that don't oblige overtime.

He concluded by asking for punitive overtime rates to force hospitals to cut overtime, a policy that is strongly endorsed by the BMA. The unacceptably long hours of junior staff have been shown (once again) in a comprehensive interim report, Patterns of Hospital Medical Staffing. Funior Doctors' Hours, by Dr Robin Dowie of the British Postgraduate Medical Federation ( $p$ 472). The report shows that in 1987-8 in a survey of the week's work of over 400 juniors the average number of hours on duty was 90 , with doctors on duty from Friday to Monday averaging 124 hours for the week. but with no evidence from the United dom or elsewhere to prove them. Is this simply political overenthusiasm or disinformation in the tradition of "repeat something often enough and people will believe it"?

A clear example of disinformation is the misuse by ministers of doctors' "expressions of interest" in self governing units. Many doctors have expressed an interest simply to obtain more information on a proposal notable for its vagueness. Yet ministers have claimed that these show support for the concept. Similar tactics have been deployed in the push towards budget holding by general practitioners. Furthermore, ministers have constantly referred to support from doctors for their proposed changes with no supporting evidence provided for the claims Is this political hype or disinformation?

\section{Junior doctors' long hours}

What stirred me to chase this particular propaganda hare was a letter in the Guardian (9 February)from Dr Brian Tehan, president of the junior doctors' mess at Glan Clwyd Hospital near Rhyl in Wales. He wrote:

It was with disgust (but not surprise) that I read the rates of pay for junior doctors claimed to be fact, by government information services, and the alleged impact of the proposed increases (Guardian, 3 February). At the time I was surrounded by my colleagues and not one of us was receiving anywhere near the figures.

The government's figures of junior doctors'

\section{Figures fail to reach review body}

Although the report was commissioned by the government in 1985 and was available in October 1989, ministers somehow failed, so far as I know, to pass the valuable information in it to the review body for the 1990 pay review (10 February, $p 401$ ). Adding insult to ineptitude, Virginia Bottomley, Minister for Health, told parliament that as the report covered the period before the government launched two initiatives on juniors' hours it could "not be expected to reflect progress made during the last couple of years or so." Ask any junior doctor if he thinks that that rates as disinformation.

The minister did, however, concede that the rapid pace of scientific and medical advance made" it "even more important than ever for junior doctors not be tired when carrying out their duties." How disappointing then that her meeting on 7 February with the BMA about the problem produced only a promise of more talks - no action and no extra money to resolve an unacceptable state of affairs succinctly summed up by a house

In years to come people will be as shocked by the hours we work as by young boys being sent up chimneys a century ago. Eventually doctors must work a shift system like everybody else.

SCRUTATOR officer's comment during Dr Dowie's survey: 